\title{
Interacting Science through Web Quests
}

\author{
Ahmet Unal ${ }^{1, *}$, Melek Altıparmak Karakuş ${ }^{2}$ \\ ${ }^{1}$ Faculty of Education, Kastamonu University, Turkey \\ ${ }^{2}$ Faculty of Education, Mugla Sitki Kocman University, Turkey
}

Copyright $\bigcirc 2016$ by authors, all rights reserved. Authors agree that this article remains permanently open access under the terms of the Creative Commons Attribution License 4.0 International License

\begin{abstract}
The purpose of this paper is to examine the effects of WebQuests on elementary students' science achievement, attitude towards science and attitude towards web supported education in teaching 7 th grade subjects (Ecosystems, Solar System). With regard to this research, "Science Achievement Test", "Attitude towards Science Scale" and "Attitude towards Web Supported Education Scale" have been applied to seventh grade elementary science students as pre-test and post-test. Moreover, while the experimental group was using WebQuest activities during the lesson, the control group students used concurrent Science and Technology curriculum based activities. The findings of the research have examined and analyzed through the SPSS program. The outputs showed that there emerged a meaningful difference between the control and experimental group favoring the experimental group for science achievement and attitude towards web supported education whereas no meaningful difference between control and experimental group for attitude towards science has been found.
\end{abstract}

Keywords Attitude towards Science, Attitude towards Web Supported Education, Science Achievement WebQuest

\section{Introduction}

Use of technology in learning environments is getting wider and wider day by day. Compared to preceding science curricula today, it becomes an obligatory rather than a choice to integrate educational technologies in classroom environment. Use of educational technologies in science lessons will enable students to reach valuable knowledge easily and it enhances the communication between student-student and student-teacher [1].

The Internet is one of the most effective ways to access information. The use of this unlimited information source in educational environments enables interactive, cooperative and effective student work [2]. The Use of Internet as a source of information for both inside and outside the classroom learning activities, supports the communication between teachers and students. It also enables the students to work in collaboration and allows the teacher to use active learning strategies [3]. Thus, increased participation of the learner in the learning process is enabled. In addition, Internet-based learning materials support learning outside the classroom and the efficient use of time [3].

Despite the benefits of the use of Internet in educational settings, there are some significant drawbacks. One of them is that there is a high risk for the students to reach adult content Internet sites that are not suitable for them. Schools are also responsible against the family to take measures of this matter. The second disadvantage is that the information on the Internet is not organized most of the times. Considered that the students scan the net in a one-hour lecture for information, most of their time will be elapsed for reaching the information. Another problem is the quality of the information accessed $[4,5]$.

Nowadays, classrooms are changing to be learning environments that are using web based information sources rather than accepting the textbook and teacher as the authority. As a result, to obtain reliable information on the Internet, the students need the separation and evaluation of the useful information [6]. This fact reveals the necessity of the development of educational materials with teacher guidance to use Internet in educational environments usefully.

Despite the fact that information and technology is constantly evolving and changing in our age, it is a matter of debate that the education services, especially educational technologies used in teaching and learning are not evolving coherently to this acceleration. It is stated that re-organization of the teaching and learning activities and integration of the technological developments to this process will be actualized with the adoption of contemporary approaches related to the nature of science. According to this view, information is rapidly multiplying and requiring the students to: learn to think, use the information, learn to learn, solve problems, and acquire the ability of self-study [7, 8]. Such innovation about the nature of the science makes it an obligation to use computers and Internet in the process of teaching and learning.

Being aware of this necessity, the Turkish Ministry of National Education has implemented the Fatih Project. Fatih Project aimed to ensure equality of opportunity in 
education and improve technology in the schools. To achieve this goal, it is planned to maintain Internet network infrastructure and interactive LCD whiteboards to all preschools, primary and secondary level schools. It is also planned to provide every teacher and every student a tablet computer. Moreover, to support the effective use of IT tools in the teaching-learning process, in-service trainings having been scheduled for the teachers. In this process, the curriculum is being reconstructed to be aligned with the IT-assisted education and educational e-contents are being created by the Ministry of Education. The use of IT tools in the process of teaching and learning effectively was the main purpose. Given the importance attached to Fatih Project by the Ministry of Education, this research is becoming much more meaningful.

Teaching with WebQuest is an effective method to use Internet in educational environments [9]. With this learning method, the students are enabled to achieve information and construct their own knowledge through using the technology in the process of learning. Constructing their own knowledge is essential in constructivist approach. By using this method, some drawbacks of using Internet in the learning environments will be surpassed, such as difficulty in eliminating useless information, spending excess amount of time to find appropriate information, and difficulty in recognizing quality information.

The WebQuest idea was developed by the Professor Bernie Dodge of Sandiago State University in 1995. A WebQuest is an Internet-based didactic educational resource. Also as Dodge [9] pointed out, it is an inquiry-oriented lesson format in which most or all the information that learners work with comes from the web. Bernie Dodge and Tom March published various WebQuests applications within the developed framework and created a portal of WebQuest. This portal was developed and is still developing with the contribution of many teachers.

A WebQuest may be for a single field or may be interdisciplinary and held under two headings according to its duration such as short-term and long-term WebQuest. Short-term WebQuests lasts one or two lectures, and long-term WebQuest consists of activities lasting a week or a month [10, 11]. A WebQuest has 6 essential parts: introduction, task, process, resources, evaluation, and conclusion.

The purpose of the introduction section is to both prepare and interest the reader. The student is the intended audience. This section should be constructed to motivate learners to participate. It is also in this section that the students face the Big Question (Essential Question, Guiding Question) that the whole WebQuest is centered around. The task section focuses learners on what they are expected to do specifically, the culminating performance or product that drives all of the learning activities. Process step can be considered as a lesson plan. What tools the students will use for their research and the roles of these steps in the process are explained in detail. If group work is to be done, the roles in group should be clearly defined. Resources steps consist of the links offered about the subject. The first developed applications resources were located as a separate section in the WebQuest. However, in newly developed WebQuests, resources are located under the process [10-12]. The Evaluation section describes the criteria to evaluate performance and content standards, and it describes how the learners' performance would be evaluated. The assessment rubric(s) or checklist should align with the culminating project or performance, as outlined in the task section of the WebQuest. The conclusion brings closure and encourages reflection. It summarizes what the learners will have accomplished or learned by completing this activity or lesson and includes some rhetorical questions to encourage the students to extend their thinking into other content beyond the lesson.

The critical steps of the WebQuests are identified by Dodge [9] as mentioned above. This can be considered as a frame for a scaffolded learning environment since the purpose of this technique is to establish a learning environment where the students can gain higher order thinking skills through using Internet resources and get help from the guided process steps. The steps may change accordingly with the educational purpose. Some WebQuests consist of teacher page to guide the teacher who is going to benefit from the WebQuest. Young and Wilson [13] added two more parts to the WebQuest as "what do you think" and "Share and compare". These steps tend to identify the students' backgrounds about the topic and provide environment to communicate and socialize.

\section{Method}

The data related to this research was collected from a public elementary school in Mugla province of Turkey. Quasi-experimental design with pre-test and post-test and control group was established for the research.

\subsection{Study Group}

The contributors of this research were 7th grade students in the central district of Mugla province of Turkey. The study was carried in a public elementary school in the central district of Mugla. The study group consisted of 49 students where 24 of them were experimental group and 25 of them were the control group. The two classes were randomly chosen from intact classes and quasi-experimental research design established.

\subsection{Instrument and Data Collection Process}

The data collection instruments, used for this research, are given below;

- T1: Science Achievement Test

- T2: Attitude Towards Science Scale

- T3: Attitude Towards Web Supported Education Scale

Experimental and control group students firstly took 
science and technology courses using the classical teaching method. In this condition, both groups are subjected to "Science Achievement Test", "Attitude towards Science Scale" and "Attitude towards Web Supported Education Scale" referred as pre-tests. After this, while the control group kept taking courses with the use of classical teaching methods, the experimental group took its courses using WebQuest. In this condition, both groups were subjected again to "Science Achievement Test", "Attitude towards Science Scale" and "Attitude towards Web Supported Education Scale" referred as post-tests. The set of tests in both conditions were evaluated and compared, to assess the benefit of using WebQuest.

\subsubsection{Science Achievement Test}

The "Science Achievement Test" consists of 38 questions and addresses the students' science achievement level of ecosystems subject and solar system subject. For the creation of this instrument, the literature has been scanned and at least one question formula-ted for each of the acquisitions for each of the topics indicated in the curriculum. After the peer review the instrument is settled up with 38 questions. Pilot studies of the instrument were made in three different public schools in Mugla province with 110 students. The KR-20 reliability coefficient was determined to be 0.828 .

\subsubsection{Attitude towards Science Scale}

In this study, in order to measure students' attitudes towards science, "Attitude towards Science Scale" was prepared. Attitude here refers to good disposition for the Science and Technology course. The attitude scale consists of 31 items and 16 of them are positive while 15 of them are negative. Pilot studies of the instrument were made in three different public schools in Mugla province with 110 students. The Cronbach's alpha reliability coefficient was determined to be 0.923 .

\subsubsection{Attitude towards Web Supported Education Scale}

In this study, in order to measure students' attitudes towards web supported study, "Attitude towards Web Supported Education Scale" was prepared. Attitude here refers to good disposition for Web Supported Education. Attitude scale consists of 40 items. Pilot studies of the instrument were made in three different public schools in Mugla province with 110 students. Cronbach's alpha reliability coefficient of the scale was determined to be 0.776 .

\section{Findings}

In order to examine the effects of the WebQuest method on the 7th grade students' academic achievement in Science and Technology courses, the control and experimental group students' initial academic levels were identified in terms of equality. For this purpose, the experimental and the control group pre-test scores' mean and standard deviations were calculated and t-test was performed on the difference between the mean scores of the two groups to determine whether the difference is significant or not. The mean score of the control group was found to be $(X=13.08)$, and the mean score of the experimental group was $(X=16.58)$. The mean difference between the two groups was examined by the t-test and found that there is no significant difference since ( $p>05)$. In accordance with this finding, the experimental group and the control group considered as equivalent before the treatment in terms of Science and Technology success.

After the treatment, science achievement test scores were examined to see the students' science achievement levels and to examine if there is any significant difference between experimental and control groups. For this purpose, the experimental and the control group post-test scores', mean and standard deviations were calculated and on the difference between the mean scores of the two groups, t-test was performed to determine whether the difference is significant or not. The mean score of the experimental group $(X=24,17)$ was calculated to be higher than the mean score of the control group $(X=16,80)$. In order to see if this difference is significant or not, t-test was performed and the difference was found to be significant $(\mathrm{p}<.05)$. In line with these findings, it can be said that WebQuest method can improve academic achievement in Science and Technology courses.

The control group and the experimental group pre-test and post-test mean scores are examined and there are significant differences in the success of both groups, but it is obvious that the experimental group students' science achievements (WebQuest teaching method applied) were higher than those of control group students. This implied that WebQuest teaching method is more effective than the classical method in academic success of students in Science and Technology course.

The effects of the WebQuest method on 7th grade students' attitudes towards science were analyzed and firstly their initial attitude levels were identified to see if the control and experimental groups were equivalent. With this purpose, the experimental and the control group pre-test scores gathered from the attitudes towards science scale. The mean and standard deviations were calculated and t-test was performed on the difference between the mean scores of the two groups to determine whether the difference is significant or not.

The mean score of the control group in attitudes towards science scale was $(X=111.76)$ and the mean score of the experimental group was $(X=114.63)$. The difference between mean scores of the attitudes towards science scale of the two groups were examined by the t-test and found that there was no significant difference since ( $p>05)$. Under the light of this finding, the experimental group and the control group considered as equivalent before the treatment in terms of attitude levels towards science. 
After the treatment, attitudes towards science scale scores were examined to identify the students' attitude levels and to see if there is any significant difference between experimental and control group's' scores. For this purpose, the experimental and control group post-test scores mean and standard deviations were calculated and t-test was performed on the difference between the mean scores of the two groups to determine whether the difference is significant or not.

The mean score of the experimental group $(X=120.67)$ was higher than the mean score of the control group $(X=113.68)$. In order to see if this difference is significant or not, t-test was performed and the difference was found not to be significant ( $p>.05)$. In line with these findings, it can be said that WebQuest method cannot improve attitude towards science much higher than classical methods in Science and Technology courses. When the control group and the experimental group pre-test and post-test mean scores considered an increase emerged of both groups' attitudes towards science levels but this difference was not significant.

In order to examine the effects of the WebQuest method on 7th grade students' attitudes towards web supported learning, firstly their initial attitude levels were identified to see if the control and experimental groups were equivalent. With this purpose, the experimental and the control group pre-test scores gathered from the attitudes towards web supported education scale. The mean scores and standard deviations were calculated and t-test was performed on the difference between the mean scores of the two groups to determine whether the difference is significant or not. The mean score of the control group in attitudes towards web supported education scale was $(X=129,84)$ and the mean score of the experimental group was $(X=133,92)$. The difference between mean scores of the attitudes towards web supported education scale of the two groups were examined by the t-test and found that there is no significant difference since $(p>.05)$. This finding indicated that, the experimental group and the control group can be considered as equivalent before the treatment in terms of attitude levels towards web supported learning.

After the treatment, attitudes towards web supported education scale scores were examined to identify the students' attitude levels and to see if there is any significant difference between experimental and control group's' scores. For this purpose, the experimental and control group post-test scores mean and standard deviations were calculated and t-test was performed on the difference between the mean scores of the two groups to determine whether the difference is significant or not.

The mean score of the experimental group $(X=144,38)$ was higher than the mean score of the control group $(X=131,44)$. In order to see if this difference is significant or not, $\mathrm{t}$-test was performed and the difference was found to be significant $(\mathrm{p}<.05)$. In line with these findings, it can be said that WebQuest method can improve attitude towards web supported learning in Science and Technology courses.
Any comments and suggestions are welcomed so that we can constantly improve this template to satisfy all authors' research needs.

\section{Discussion and Conclusion}

In this research, the experimental group was treated by WebQuest method and the control group was treated by classical methods present in the curriculum in the science and technology course.

Before the treatment, there found no significant difference between the mean values of control group's science achievement pre-test score $(X=13.08)$ and experimental group's science achievement pretest score $(X=16.58)$. Closer science achievement scores of students in each group, and the absence of any statistical difference between the scores is the expected result. This can be explained with the fact that both groups' preceding courses are depending on the same curriculum and same methods.

A significant difference was found between the mean values of post-test science achievement scores $(X=24,17)$ of the students treated with WebQuest method and post-test science achievement scores $(X=16,80)$ of the students treated with classical methods present in the curriculum favoring the WebQuest method. Allowing students to work outside the traditional classroom setting, to obtain and construct their own knowledge, using the Internet as a resource of information can be counted as the factors leading to this difference. Gorghiu et. al. [14] identified with their research that WebQuest Method allows students to work collaboratively, inspires teachers for classroom activities, makes it possible to integrate Internet to the learning environments, and motivates students positively. In a survey conducted by K1lıç [15] it is found that students treated by WebQuest method achieve higher than the students that treated by traditional methods and another group with collaborative work environment.

The difference between the mean values of the experimental group's pre-test science achievement scores $(\mathrm{X}=16.58)$ and post-test science achievement scores $(X=24,17)$ found to be significantly different favoring the post-test scores. Experimental group students treated with a teaching method other than the traditional methods present in the curriculum and this influenced their science achievement positively. With the WebQuest method, they realized that the Internet can be used as a rese-arch tool and they improved their research skills. Moreover, they get some idea about how to use time effectively. All of these listed factors played an active role in the success of the students. Lipscomb [16] identified that WebQuest method contributes to the development of creativity. Hassanien [17] indicated that WebQuest method makes it possible to gather information form the Internet as well as it is helpful to get access to information sources. All these findings are in line and complementary with this research.

It is the difference between the mean values of pre-test science achievement scores $(X=13.08)$ and post-test science 
achievement scores $(X=16,80)$ of the control group students showed that there is a fair improvement in students' science achievement. However, this increase was not as high as in the experimental group. The reason of this situation can be explained by the fact that the control group students continue their education in the same learning environment with no changes. The students with high attitude towards the lesson continued to keep their interest in the lesson while others could found no motive force to get them interested in the lesson. It is revealed that, in order to increase students' success, a learning environment that attracts their interest and enhances their comfort is necessary.

Before the treatment, there found no significant difference between the mean values of the control group students' attitudes towards science scale scores $(X=111.76)$ and experimental group students' attitudes towards science scale scores $(X=114.63)$. After the treatment, it can be seen that there is some improvements on the students' attitude levels towards the science and technology course since the mean value of control group students' attitudes towards science scale score is $\mathrm{X}=113.68$ and the mean value of experimental group students' attitudes towards science scale score is $X=120.67$. However, none of these improvements are statistically significant. Under the light of the related literature, this is probably because 5 weeks period of the research is not enough to result a change on the students' attitude levels towards science.

Experimental group students' pre-test scores of attitude towards web supported education scale are assumed to be equivalent to those of control group students, since there is no statistically significant difference between the mean values of control group students' attitude towards web supported education scale scores $(X=129,84)$ and experimental group students' attitude towards web supported education scale scores $(X=133,92)$. After the treatment, experimental group students' attitude levels towards web supported education are found to be much higher than the control group students' attitude levels towards web supported education. The post-test mean value of attitude towards web supported education scale scores of the experimental group students is $X=144,38$ while the post-test mean value of attitude towards web supported education scale scores of the control group students is $\mathrm{X}=131,44$ and the difference is statistically significant. Kurtuluş et.al [18] and Halat [19] found that teachers and students have positive attitudes towards WebQuest method. One reason for this is the fact that the students feel comfortable and the learning environment attracts them. The other reason is that, WebQuest method is an easy way to learn how to do research, how to find information and how to construct own knowledge. When all these factors are considered, it can be definitely said that WebQuest method boosts the students' attitude towards web supported learning.

\section{REFERENCES}

[1] I. Kos. Teaching Clinically Oriented Embryology with Computer Simulations, Doctorate Thesis, New York University, United States, 1996.

[2] R. C. Forcier. The Computer as an Educational Tool, Prentice-Hall, New Jersey, 1999.

[3] M. E. Ritter, K. A. Lemke. Addressing the 'Seven Principles for Good Practice in Undergraduate Education' with Internet-enhanced Education, Journal of Geography in Higher Education, Vol.24, No.1, 100-108, 2000.

[4] T. Yanpar. Öğretim Teknolojileri ve Materyal Tasarımı, Anı Yayınları, Ankara, 2007.

[5] M. M. Akhand,. Project Based Learning (PBL) and Webquest: New Dimensions in Achieving Learner Autonomy in a Class at Tertiary Level, Journal of Pan-Pacific Association of Applied Linguistics, Vol.19, No.2, 55-74, 2015.

[6] D. Clark. Evaluating media-enhancement and source authority on the Internet: the Knowledge Integration Environment, International Journal of Science Education, Vol.22, 859- 871, 2000 .

[7] Y. Özden. Öğrenme ve Öğretme, Pegem Akademi Yayıncılık, Ankara, 1999.

[8] L. Leite, L. Dourado, S. Morgado. "Sustainability on Earth" Webquests: Do They Qualify as Problem-Based Learning Activities?, Research in Science Education, Vol.45, No.1, 149-170, 2015.

[9] B. Dodge. FOCUS: Five Rules for Writing a Great WebQuest, Learning \& Leading with Technology, Vol.28, No.8, 2001.

[10] S. Iskeceli-Tunc, D. Oner. Use of WebQuest Design for Inservice Teacher Professional Development, Education and Information Technologies, Vol.21, No.2, 319-347, 2016.

[11] C. Kobylinski. Student Feedback on the Effectiveness of Using a Webquest for an Integrative Skills Course in a Korean University, Contemporary Issues in Education Research, Vol.7, No.1, 63-68, 2014.

[12] R.G. Chatel, J. Nodell. Webquests: Teachers and students as global literacy explorer, Paper presented at the annual meeting of the Connecticut Reading Association, Cromwell, CT. (ERIC Document Reproduction Service No. 471 843), 2002.

[13] D. L. Young, B. G. Wilson. Webquests for reflection and conceptual change: Variations on a popular model for guided inquiry, (ERIC Number: ED477112), 2002.

[14] G. Gorghiu, L. Gorghiu, V. Gonzalez, A. De La Santa. Webquest in the Classroom - Analysis of its Impact, 3rd International Conference on Multimedia and Information \& Communication Technologies in Education, 7-10 July, Caceras, Spain, 2005.

[15] R. Kılıç.. Webquest Destekli İşbirlikçi Öğrenme Yönteminin Matematik Dersindeki Tutum ve Erișiye Etkisi, Master Thesis, Osmangazi Üniversitesi Sosyal Bilimler Enstitüsü, Eskişehir, 2007.

[16] G. Lipscomb. I Guess It was Pretty Fun Using WebQuest in the Middle School Classroom, Preventing School Failure, 
Vol.76, No.3, 2003.

[17] A. Hassanien. An evaluation of the WebQuest as a computer-basd learning tool. Research in Post-Compulsor Education, Vol.11, No.2, 235-250, 2006.

[18] A. Kurtuluş, Tepe, S. Yılmaz, Ö. Karakoç, G. Okur. İlköğretim Matematik Sınıflarında Webquest Uygulamaları, 6th International Educational Technology Conference, Eastern Mediterranean Universty, Famagutsa, 1194- 1201, 2006.

[19] E. Halat. Matematik Öğretiminde Webquest' in Kullanımına ilişkin Öğretmen Adaylarının Görüşleri. İlköğretim-Online, Vol.6, No.2, 264-283, 200 